\title{
Development of a Competent and Trouble Free DNA Isolation Protocol for Downstream Genetic Analyses in Glycine Species
}

\author{
Muhammad Amjad Nawaz ${ }^{1}$, Faheem Shehzad Baloch ${ }^{2}$, Hafiz Mamoon Rehman ${ }^{1}$, Bao Le ${ }^{1}$, \\ Fahima Akther ${ }^{1}$, Seung Hwan Yang ${ }^{3}$, Gyuhwa Chung ${ }^{1 *}$
}

${ }^{1}$ Department of Biotechnology, Chonnam National University, Yeosu, Chonnam 59626, Republic of Korea

${ }^{2}$ Department of Field Crops, Faculty of Agricultural and Natural Science, Abant Izzet Baysal University, 14280 Bolu-Turkey

${ }^{3}$ Center for Nutraceutical and Pharmaceutical Materials, Myongji University, Gyeonggi 17058, Republic of Korea

A R T I C L E I N F O

Article history:

Received 12 May 2016

Accepted 05 August 2016

Available online, ISSN: 2148-127X

Keywords:

CTAB

DNA Extraction

Glycine species

Genetic analyses

PVP

\section{A B S T R A C T}

Extraction of deoxyribose nucleic acid (DNA) from plants is preliminary step in molecular biology. Fast and cost effective genomic DNA isolation from Glycine species for downstream application is a major bottleneck. Here we report a high throughput and trouble free method for genomic DNA extraction from leaf and seeds of Glycine species with high quality and quantity. Protocol reports the optimization by employing different concentrations of CTAB and PVP in extraction buffer. Efficiency of optimized protocol was compared with frequently used DNA extraction methods. Wide adoptability and utility of this protocol was confirmed by DNA extraction from leaves as well as seeds of G. max, G. soja, G. tomentella and G. latifolia. Extracted DNA was successfully subjected to PCR amplification of five microsatellite markers and four putative glycosyltransferase genes. DNA extraction protocol is reproducible, trouble free, rapid and can be adopted for plant molecular biology applications.

Corresponding Author:

E-mail: chung@chonnam.ac.kr

\section{Introduction}

The genus Glycine comprises of two subgenera viz. Glycine Willd and Soja (Moench) F. J. Hermann. Among 28 species classified under two subgenera, only two annual species G. soja Sieb \& Zucc (wild) and G. max (cultivated) are consumed as food or feed either directly or indirectly (Guo et al., 2012). The other two wild perennials viz. Glycine tomentella Hayata and Glycine latifolia (Benth.) Newell \& Hymowitz are also valuable molecular and genetic resources for investigation of biotic and abiotic stress tolerance, evolution and phylogeny (Chang et al., 2014). Extraction of DNA is a preliminary step in many biotechnological experiments including forward genetics, reverse genetics, molecular characterization, phylogenetic relationship, genetic engineering, sequencing and genomics. Owing to the importance of this necessary step in copious downstream applications, a variety of protocols have been reported for isolation of DNA from biological materials as well as many kits are commercially available. Most commonly used method for the said purpose is cetyltrimethyl ammonium bromide (CTAB) (Sahu et al., 2012). Many scientists use Qiagen DNeasy plant mini kit ${ }^{\circledR}$ and $\mathrm{Hi}$ Gene ${ }^{\circledR}$ genomic DNA prep kit due to shortage of time (Drabkova et al., 2002). Each method has advantages and disadvantages over the other. A reliable and efficient DNA extraction protocol should present higher yield with minimal degradation accompanied with reduced cost of labor and supplies as well as minimal production of hazardous waste. Secondary metabolites, polysaccharides and proteins extracted along with DNA effects the quality and inhibit analytical studies (Maliyakal, 1992; Pirttila et al., 2001). Interaction of polyphenols DNA can also hinder efficiency and activity of various enzymes used in restriction digestion, amplification and ligation (Manoj et al., 2007; Fang et al., 1992; Sharma et al., 2002). Glycine species produce higher amounts of polyphenols and secondary metabolites, which causes complications to precipitate pure and high quantity DNA (Watson, 2014). These secondary metabolites like polysaccharides and polyphenols severely affect the isolation procedure by interacting irreversibly with nucleic acid and interfere with the function of enzymes in subsequent analysis (Sahu et al., 2012; Maliyakal 1992; Demeke \& Adams 1992; Porebski et al., 1997). These contaminants prevent the use of DNA for molecular biology purposes, such as PCR, restriction digests, or sequencing by inhibiting the action of polymerases or endonucleases (Khanuja et al., 1999). 
In the present work, we objected to standardize a DNA isolation protocol for Glycine species. We also compared the described method with four commonly used methods. To assess the quality of DNA, we performed PCR amplifications of four putative glycosyltransferase genes and five microsatellite loci at various positions in the G. soja genome.

\section{Material and Methods}

\section{Plant Material}

Young trifoliate leaves of Glycine species from experimental plots of Department of Biomedical and Electrical Engineering, Chonnam National University, Yeosu, South Korea, were harvested, washed with double distilled water and then temporarily stored in $-80^{\circ} \mathrm{C}$ till DNA extraction. All fresh leaf samples were harvested from plants growing in similar environmental and agronomic conditions. Unless stated otherwise all chemicals were purchased from Sigma Aldrich Co.

\section{DNA Isolation}

Sterile mortar and pestle were used to grind $200 \mathrm{mg}$ of frozen samples with $500 \mu \mathrm{L}$ of preheated extraction buffer (20 mM EDTA-pH 8.0, 100 mM Tris-HCl-pH 8.0, $1.4 \mathrm{M} \mathrm{NaCl}, 0.2 \% \quad \beta$-mercaptoethanol, $0.7 \%$ activated charcoal, $\mathrm{X} \% \mathrm{CTAB}$ and $\mathrm{X} \% \mathrm{PVP})$. Ground material was transferred to $1.7 \mathrm{~mL}$ sterile tubes and carefully mixed by inverting tubes with hands and incubated at $65^{\circ} \mathrm{C}$ for $30 \mathrm{~min}$. Material in tubes were mixed with 3 times inverting tubes during incubation. Twenty four extraction buffers were standardized by manipulating concentration of one variable (CTAB or PVP) at a time while keeping other ingredients constant (Table 1). Supernatant was extracted by using each buffer after incubation by adding and gently mixing with chloroform:isoamyl-alcohol $(24: 1, \mathrm{v} / \mathrm{v})$ in equal volumes and centrifuging at $10400 \mathrm{X} \mathrm{g}$ for $5 \mathrm{~min}$ at room temperature. Supernatant was mixed with equal volume of chilled 2-propanol and kept in ice for $5 \mathrm{~min}$ to precipitate DNA. Pellet was harvested by centrifuging the mixture at $15000 \mathrm{X} \mathrm{g}$ for 5 minutes at room temperature. Pellet was washed with $500 \mu \mathrm{L} \mathrm{70 \%} \mathrm{ethanol} \mathrm{twice} \mathrm{and} \mathrm{air} \mathrm{dried} \mathrm{for} 2$ hrs. Dried pellet was dissolved in $100 \mu \mathrm{L} 0.5 \mathrm{X}$ TAE buffer and $10 \mathrm{mg}$ of Ribonuclease $\mathrm{A}$ was added and incubated for $30 \mathrm{~min}$ at $37^{\circ} \mathrm{C}$. Post RNaseA treatment, DNA was precipitated by using chloroform;isoamylalcohol (24:1, v/v) and chilled 2-propanol as mentioned earlier. $50 \mu \mathrm{L}$ of $5 \mathrm{M}$ sodium acetate was added prior to 2 propanol precipitation. Pallet was washed with $70 \%$ ethanol, air dried, dissolved in $100 \mu \mathrm{L} 0.5 \mathrm{X}$ TAE buffer and stored at $4^{\circ} \mathrm{C}$ for further studies.

The DNeasy ${ }^{\circledR}$ plant mini kit (Qiagen 69104) followed quick starter protocol. Each sample was lysed using sterile pestle and mortar in $400 \mu \mathrm{l}$ buffer AP1 and incubated at $65^{\circ} \mathrm{C}$ for 10 min after adding RNase A. DNA was bound, washed and eluted by employing QIAshredder spin column and DNeasy mini spin column by using buffer P3 AW1, AW2 and AE, respectively.

Table 1 Effect of different concentrations of CTAB and PVP on quality and quantity of DNA of G. soja.

\begin{tabular}{|c|c|c|c|c|}
\hline CTAB Conc. $(\%)$ & PVP Conc. $(\%)$ & DNA Conc. $n g / \mu \mathrm{L}$ & A260/A280 & Lane \\
\hline 1.5 & 1 & $1812 \pm 420^{\mathrm{bc}}$ & $1.96 \pm 0.28^{b}$ & \\
\hline 2.0 & 1 & $1525 \pm 335^{b c}$ & $2.23 \pm 0.57^{\mathrm{b}}$ & $x^{2}=4$ \\
\hline 2.5 & 1 & $2951 \pm 883^{b}$ & $1.85 \pm 0.13^{\mathrm{b}}$ & ent \\
\hline 3.0 & 1 & $1488 \pm 313^{b c}$ & $2.22 \pm 0.51^{\mathrm{b}}$ & 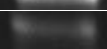 \\
\hline 3.5 & 1 & $1295 \pm 898^{\mathrm{bc}}$ & $2.13 \pm 0.65^{\mathrm{b}}$ & 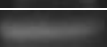 \\
\hline 4.0 & 1 & $2035 \pm 810^{\mathrm{bc}}$ & $1.81 \pm 0.01^{\mathrm{b}}$ & (n) \\
\hline 1.5 & 2 & $2413 \pm 693^{b c}$ & $1.79 \pm 0.26^{\mathrm{b}}$ & C. \\
\hline 2.0 & 2 & $828 \pm 605^{\mathrm{bc}}$ & $2.07 \pm 0.53^{b}$ & 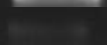 \\
\hline 2.5 & 2 & $2102 \pm 686^{b c}$ & $1.69 \pm 0.37^{\mathrm{b}}$ & \\
\hline 3.0 & 2 & $1222 \pm 737^{\mathrm{bc}}$ & $2.01 \pm 0.23^{\mathrm{b}}$ & 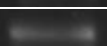 \\
\hline 3.5 & 2 & $753 \pm 429^{b c}$ & $2.24 \pm 0.72^{\mathrm{b}}$ & 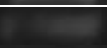 \\
\hline 4.0 & 2 & $1381 \pm 328^{b c}$ & $2.20 \pm 0.82^{\mathrm{b}}$ & 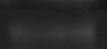 \\
\hline 1.5 & 3 & $575 \pm 396^{\mathrm{c}}$ & $2.66 \pm 0.77^{\mathrm{b}}$ & a \\
\hline 2.0 & 3 & $1381 \pm 1381^{b c}$ & $0.87 \pm 0.87^{\mathrm{b}}$ & -4 \\
\hline 2.5 & 3 & $1771 \pm 89^{\mathrm{bc}}$ & $1.75 \pm 0.21^{\mathrm{b}}$ & \\
\hline 3.0 & 3 & $4979 \pm 1098^{a}$ & $1.89 \pm 0.07^{\mathrm{b}}$ & Ex \\
\hline 3.5 & 3 & $1982 \pm 41^{\mathrm{bc}}$ & $2.04 \pm 0.06^{\mathrm{b}}$ & 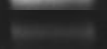 \\
\hline 4.0 & 3 & $920 \pm 611^{b c}$ & $2.16 \pm 0.01^{\mathrm{b}}$ & 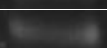 \\
\hline 1.5 & 4 & $389 \pm 389^{c}$ & $0.99 \pm 0.99^{\mathrm{b}}$ & $e^{2}$ \\
\hline 2.0 & 4 & $923 \pm 625^{b c}$ & $2.20 \pm 0.28^{\mathrm{b}}$ & 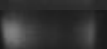 \\
\hline 2.5 & 4 & $1693 \pm 253^{b c}$ & $1.73 \pm 0.15^{\mathrm{b}}$ & 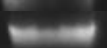 \\
\hline 3.0 & 4 & $787 \pm 729^{b c}$ & $6.05 \pm 4.27^{\mathrm{a}}$ & 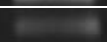 \\
\hline 3.5 & 4 & $1632 \pm 34^{\mathrm{bc}}$ & $1.84 \pm 0.33^{\mathrm{b}}$ & 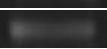 \\
\hline 4.0 & 4 & $1893 \pm 526^{\mathrm{bc}}$ & $2.25 \pm 0.24^{\mathrm{b}}$ & \\
\hline
\end{tabular}

Note: Values (means $\pm \mathrm{SD})$ with different superscript in a column show significant differences $(\mathrm{P}<0.05)$. 
Table 2 Putative glycosyltransferase genes used for gene specific PCR in G. soja.

\begin{tabular}{l|clc}
\hline No. & Gene ID & \multicolumn{1}{c}{ Forward \& reverse Primer Sequence } & Tm $\left({ }^{\circ} \mathrm{C}\right)$ \\
\hline 1 & \multirow{2}{*}{ Glyma10g107900 } & F: ATGGCTTCGAGTGGAAAAAT & 53.8 \\
& & R: CTAATTAGTGATATGAGCTATGAAAGACTC & 52.7 \\
2 & Glyma10g108400 & F: CAAGCGAGCTTTTAAGATTGG & R: ACACGATTTTGTGCGTGAAA \\
3 & Glyma10g104700 & F: TAATTGTGGATTGCGCTGAG & R: CATGATGATGATTGAAGATTGGA \\
& & F: GGTGTCCACCAGGCCACTAT & 52.7 \\
4 & Glyma10g109400 & R: TGGTCTTGACCAAAATCAGTAGG & 52.7 \\
\hline
\end{tabular}

Table 3 Microsatellite markers used for PCR amplification in G. soja.

\begin{tabular}{|c|c|c|c|c|c|}
\hline No. & Gene ID & $\begin{array}{l}\text { Forward \& reverse } \\
\text { Primer Sequence }\end{array}$ & Motif & $\begin{array}{l}\mathrm{Tm} \\
\left({ }^{\circ} \mathrm{C}\right)\end{array}$ & Chromosome ID \\
\hline 1 & $\begin{array}{l}\text { BARCSOYSSR } \\
\_20 \_0274\end{array}$ & $\begin{array}{l}\text { F: GAGCAGAATTTGTGCCATCA } \\
\text { R: GCCAATGAGAGGATTCAACAA }\end{array}$ & $(\mathrm{ATA}) 20$ & 60 & Gm20 \\
\hline 2 & $\begin{array}{l}\text { BARCSOYSSR } \\
\_10 \_0717\end{array}$ & $\begin{array}{l}\text { F: CATCTTTCCTTGGCTTAGCG } \\
\text { R: TCCGGAAGCAGATTGGATAC }\end{array}$ & $(\mathrm{AAT}) 10$ & 60 & Gm10 \\
\hline 3 & $\begin{array}{l}\text { BARCSOYSSR } \\
\_10 \_0968\end{array}$ & $\begin{array}{l}\text { F: TTTGGGAACGAATTTATCGG } \\
\text { R: TTTTGAAAATGGCGTACTAGTTT }\end{array}$ & $(\mathrm{AAT}) 11$ & 60 & Gm10 \\
\hline 4 & $\begin{array}{l}\text { BARCSOYSSR } \\
\text { _20_0348 }\end{array}$ & $\begin{array}{l}\text { F: AGGTTGTTGTGTTGGGAAGTG } \\
\text { R: AATGAGCTCAATCTCAGAAACG }\end{array}$ & $\begin{array}{l}(\mathrm{TAT}) 23 \\
\operatorname{tg}(\mathrm{TTA}) 5\end{array}$ & 60.6 & Gm20 \\
\hline 5 & $\begin{array}{l}\text { BARCSOYSSR } \\
\_10 \_0968\end{array}$ & $\begin{array}{l}\text { F: TTTGGGAACGAATTTATCGG } \\
\text { R: TTTTGAAAATGGCGTACTAGTTT }\end{array}$ & $(\mathrm{AAT}) 11$ & 60.6 & Gm10 \\
\hline
\end{tabular}

HiGene $^{\mathrm{TM}}$ genomic DNA prep kit for plant tissues also used column type extraction strategy. Leaf sample frozen at $-80^{\circ} \mathrm{C}$ was ground with SGD1 buffer and incubated at $65^{\circ} \mathrm{C}$ for $10 \mathrm{~min}$ after adding proteinase $\mathrm{K}$. DNA was bound to spin column, washed and eluted by using SuperBinder ${ }^{\mathrm{TM}}$ solution, WB solution, and DNA hydration solution, respectively.

To find out the wide applicability of the standardized protocol, four Glycine species i.e G. soja, G. max, $G$. latifolia and $G$. tomentella were included in the studies. Furthermore, the selected optimized method was applied to isolate DNA from fresh trifoliate leaves as well as seeds. For isolation of DNA from seeds, seed coat of 200 $\mathrm{mg}$ seeds was removed, seeds were ground in sterile pestle and mortar, then processed as mentioned above.

\section{Quantification of DNA}

DNA quantification was done by using ACTGene ASP-2680 spectrophotometer (CellTAGen, Korea) by using an aliquot of $1 \mu \mathrm{l}$ from the stock. The concentration and purity of the extracted DNA was measured at $260 \mathrm{~nm}$ and A260/A280 ratio, respectively. The bands were observed, documented and analyzed using a gel doc system (Davinch-GelTM Gel Imaging System, Korea). Mean values and standard deviations were computed in SPSS 22.0.0.1 (IBM Co, USA).

\section{PCR Microsatellite Analysis}

The extracted genomic DNA was subjected to microsatellite analysis. We employed five pairs of microsatellites (Table 3) located on different linkage groups. Briefly, the reactions were carried out in a thermal cycler (Takara, Japan) at $94^{\circ} \mathrm{C}$ for $4 \mathrm{~min}$, followed by 35 cycles each of $30 \mathrm{~s}$ at $94^{\circ} \mathrm{C}, 30 \mathrm{~s}$ at about $60^{\circ} \mathrm{C}$ and $90 \mathrm{~s}$ at $72^{\circ} \mathrm{C}$ and finally maintained at $4^{\circ} \mathrm{C}$ in a volume of $20 \mu \mathrm{L}$ [1X buffer, $0.2 \mathrm{mM}$ of dNTP, $0.3 \mu \mathrm{M}$ of primer pairs, $1 \mathrm{U}$ of polymerase (Ex-Taq, Takara, Japan) and $1-5 \mathrm{ng}$ of genomic DNA]. $5 \mu \mathrm{L}$ of PCR product was used for agarose gel electrophoresis and the results were visualized in gel doc system.

\section{Gene Specific PCR Analysis}

PCR amplification of 4 putative glycosyltransferase genes (Table 2) were carried out in $25 \mu \mathrm{L}$ reactions (1 U Ex-taq DNA polymerase, $1 \mathrm{mM}$ dNTPs, $1 \mathrm{X}$ Taq buffer, $20 \mathrm{mM}$ of forward and reverse primer, and $30 \mathrm{ng}$ of template DNA) in thermal cycler at $95^{\circ} \mathrm{C}$ for $5 \mathrm{~min}$. followed by 35 cycles each at $95^{\circ} \mathrm{C}$ for $30 \mathrm{~s}, 52.7-53.8^{\circ} \mathrm{C}$ for $30 \mathrm{~s}$ and $72^{\circ} \mathrm{C}$ for $2 \mathrm{~min}$. followed by one cycle of final amplification at $72^{\circ} \mathrm{C}$ for $10 \mathrm{~min}$. PCR amplified products were examined by employing agarose $(1.2 \%)$ gel electrophoresis buffered with $0.5 \mathrm{X}$ TAE. Visualization was performed by staining gels with ethidium bromide and observed under UV light in gel documentation system.

\section{Results and Discussion}

Extraction of high quality of DNA from plant samples has been always challenging and foremost requirement for molecular biology studies. However, DNA extraction with higher yields and good quality has always not been successful from number or economically and medicinally important plants owing to the presence of polyphenols and secondary metabolites (Mesquita et al., 2015). Numerous challenges were faced while DNA extraction from different accessions of wild members of genus Glycine while following the protocol of Doyle and Doyle, (1987). Method described by Habere et al., (1996) yielded sticky and brownish pellets which were contaminated by 
phenolic compounds. Moreira and Oliveira, (2011) also encountered colored pallets contaminated with phenolic compounds. Among 24 combinations of CTAB and PVP the maximum DNA yield of $4979 \pm 1098 \mathrm{ng} / \mu \mathrm{L}$ with A260/A280 ratio of $1.89 \pm 0.07$ was recorded in extraction buffer containing 3\% CTAB and 3\% PVP. Pallet color was white with no visible discoloration. While minimum DNA yield i.e $389 \pm 389 \mathrm{ng} / \mu \mathrm{L}$ with $\mathrm{A} 260 / \mathrm{A} 280$ ratio of $0.99 \pm 0.99$, was recorded in extraction buffer augmented with $1.5 \%$ CTAB and 4\% PVP (Table 1).

We compared the efficiency of our optimized protocol with frequently used DNA extraction methods i.e. Habere et al., (1996), Doyle and Doyle, (1987), DNeasy ${ }^{\circledR}$ plant mini kit and HiGene ${ }^{\mathrm{TM}}$ genomic DNA prep kit. Protocol reported by Habere et al., (1996) though gave acceptable quantities of DNA i.e $1168.9 \pm 38.90 \mathrm{ng} / \mu \mathrm{L}$ with $\mathrm{A}$ $260 / 280$ ratio of $2.03 \pm 0.79$ but the quality was compromised. On the contrary, method reported by Doyle and Doyle, (1987) yielded very low concentration of DNA i.e $278.5 \pm 53.45 \mathrm{ng} / \mu \mathrm{L}$ with A $260 / 280$ ratio of $1.23 \pm 0.10$. The comparative data of isolated DNA concentrations and absorbance ratios of four reported methods and optimized method is presented in Table 4. Use of commercial kits viz. DNeasy ${ }^{\circledR}$ plant mini kit and HiGene $^{\mathrm{TM}}$ genomic DNA prep kit resulted in lighter smear tail and acceptable quality and quantity (Table 4). The developed method yielded high quantity of DNA which differed significantly from other tested methods. The high yield of DNA (4979.0 \pm 410.50$)$ proved that the developed method is a better option for applications where higher amounts of DNA is required. The quality of extracted DNA using new developed method was very ideal (1.78 \pm 0.08$)$. Keeping in view the quality and quantity of isolated DNA by our method, the method proved to be highly reliable and efficient.

It has been reported that $2 \% \mathrm{CTAB}$ concentration in extraction buffer improves cell membrane disruption (Doyle \& Doyle, 1987; Bhau, et al., 2015). We employed 6 different concentrations of CTAB $(1.5,2.0,2.5,3.0,3.5$ and $4.0 \%$ ). In present experiment extraction buffer containing 3\% CTAB produced highest quantity of DNA i.e $4979 \pm 1098 \mathrm{ng} / \mu \mathrm{L}$ with A260/A280 1.89 \pm 0.07 . DNA yield and A260/A280 ratios for all six concentrations of $\mathrm{CTAB}$ in relation to different concentrations of PVP are presented in Table 1. Considering role of PVP in removing contamination during DNA extraction (Malencic et al., 2012; Dolatabadi et al., 2010; Bressan et al., 2014) four PVP concentrations were used (1, 2, 3 and $4 \%$ ). Many researchers examined the effect of PVP on the quality and quantity of DNA in plants with higher levels of polyphenols and antioxidants (BHAU et al., 2015; Kit \& Chandran 2013). We witnessed highest quantity of DNA (4979 $\pm 1098 \mathrm{ng} / \mu \mathrm{L}$ with A260/A280 ratio1.89 \pm 0.7 ) with the extraction buffer having $3 \%$ PVP. In contrast to this best quality DNA isolation was recorded in buffer containing 1\% PVP $(2035 \pm 810 \mathrm{ng} / \mu \mathrm{L}$ with A260/A280 ratio of $1.81 \pm 0.01$. Use of $\beta$-mercaptoethanol also helps to remove phenolic compounds during DNA isolation (Suman et al., 1999). Therefore, addition of $0.2 \% \beta$ mercaptoethanol helped to make the protocol good to yield higher quality and quantity of DNA. Addition of $0.7 \%$ activated charcoal in extraction buffer helps to bind with resinous materials and negates the possibility of coextraction of impurities. Furthermore, its role in absorbing colored impurities and removing polyphenols also supports our method as previously reported by Bhau et al., (2015).

Table 4 Comparison of quality and quantity of DNA extracted with four previously reported method and new optimized method in G. soja.

\begin{tabular}{l|ccccc}
\hline \multicolumn{1}{c|}{ Method } & $\begin{array}{c}\text { DOYLE \& DOYLE } \\
(1987)\end{array}$ & $\begin{array}{c}\text { HABERE et al } \\
(1996)\end{array}$ & $\begin{array}{c}\text { DNeasy }{ }^{\circledR} \text { plant } \\
\text { mini kit }\end{array}$ & $\begin{array}{c}\text { HiGene }{ }^{\mathrm{TM}} \text { genomic } \\
\text { DNA prep kit }\end{array}$ & $\begin{array}{c}\text { New Optimized } \\
\text { Method }\end{array}$ \\
\hline Lane & & & & & \\
& & & & & \\
DNA & $278.5 \pm 53.45^{\mathrm{d}}$ & $1168.9 \pm 38.90^{\mathrm{c}}$ & $2038.5 \pm 109.89^{\mathrm{b}}$ & $1808.7 \pm 114.58^{\mathrm{b}}$ & $4979.0 \pm 410.50^{\mathrm{a}}$ \\
A260/A280 & $1.23 \pm 0.10^{\mathrm{b}}$ & $2.03 \pm 0.79^{\mathrm{a}}$ & $1.87 \pm 0.03^{\mathrm{a}}$ & $1.87 \pm 0.13^{\mathrm{a}}$ & $1.78 \pm 0.08^{\mathrm{a}}$ \\
\hline
\end{tabular}

Note: Values (means $\pm \mathrm{SD})$ with different superscript in a row show significant differences $(\mathrm{P}<0.05)$; DNA: DNA Conc. $(\mathrm{ng} / \mu \mathrm{L})$

Table 5 Comparison of quality and quantity of extracted DNA from fresh leaf and seeds of four Glycine species.

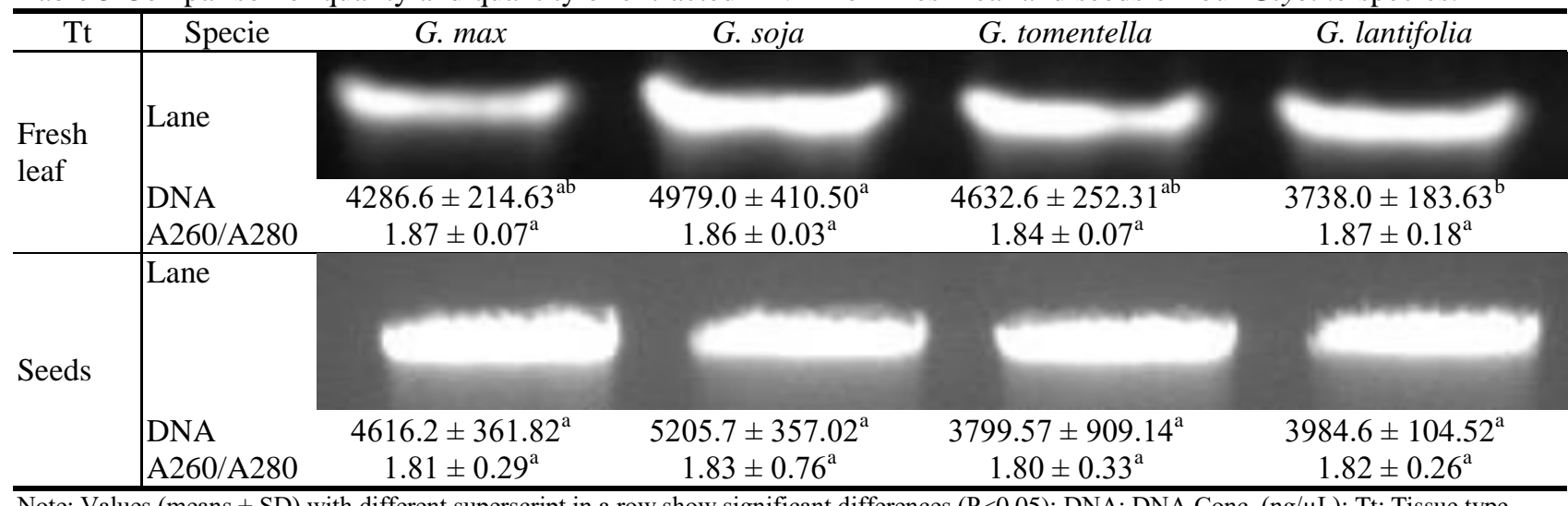




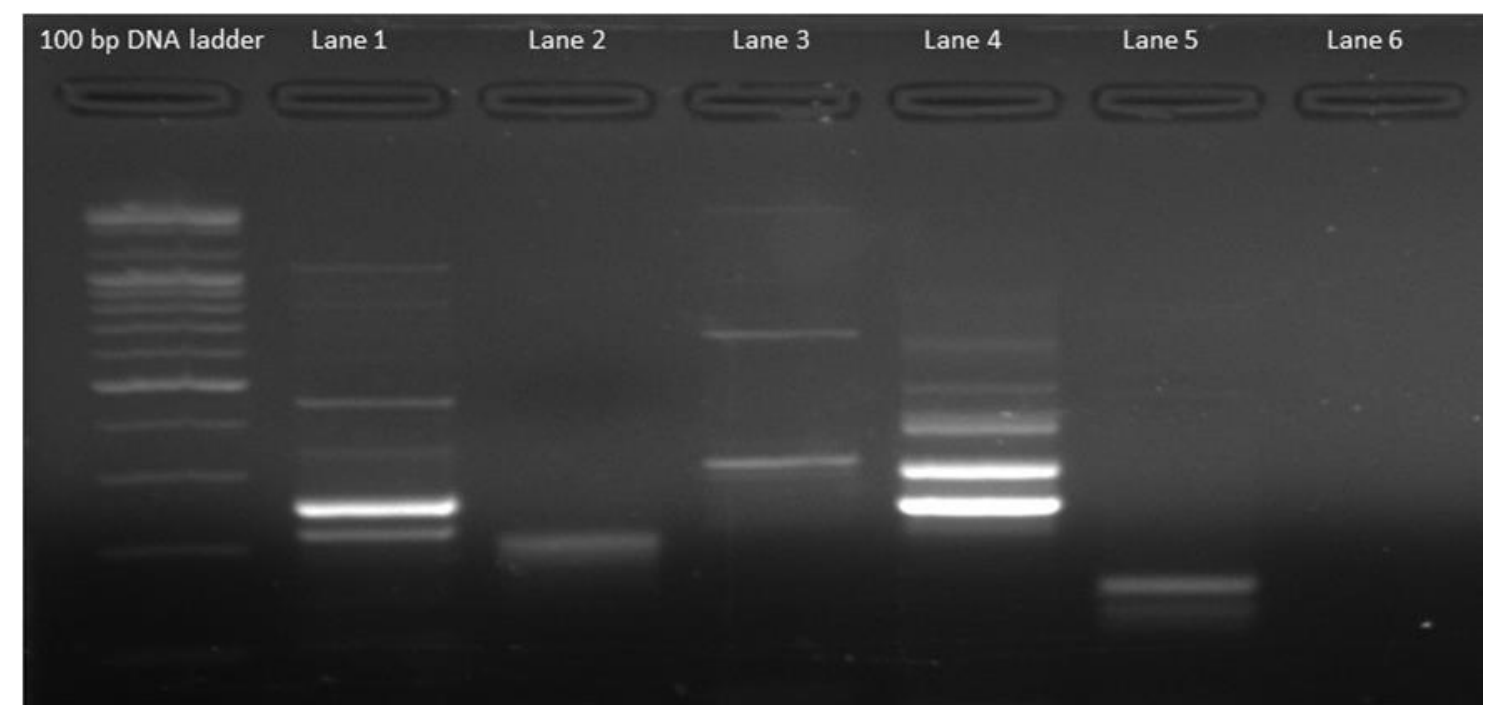

Figure 1 PCR amplification of five microsatellites in G. soja. Lane 1: BARCSOYSSR_20_0274, Lane 2: BARCSOYSSR_10_0717, Lane 3: BARCSOYSSR_10_0968, Lane 4: BARCSOYSSR_20_0348, Lane 5: BARCSOYSSR_10_0968 and Lane 6: negative control.

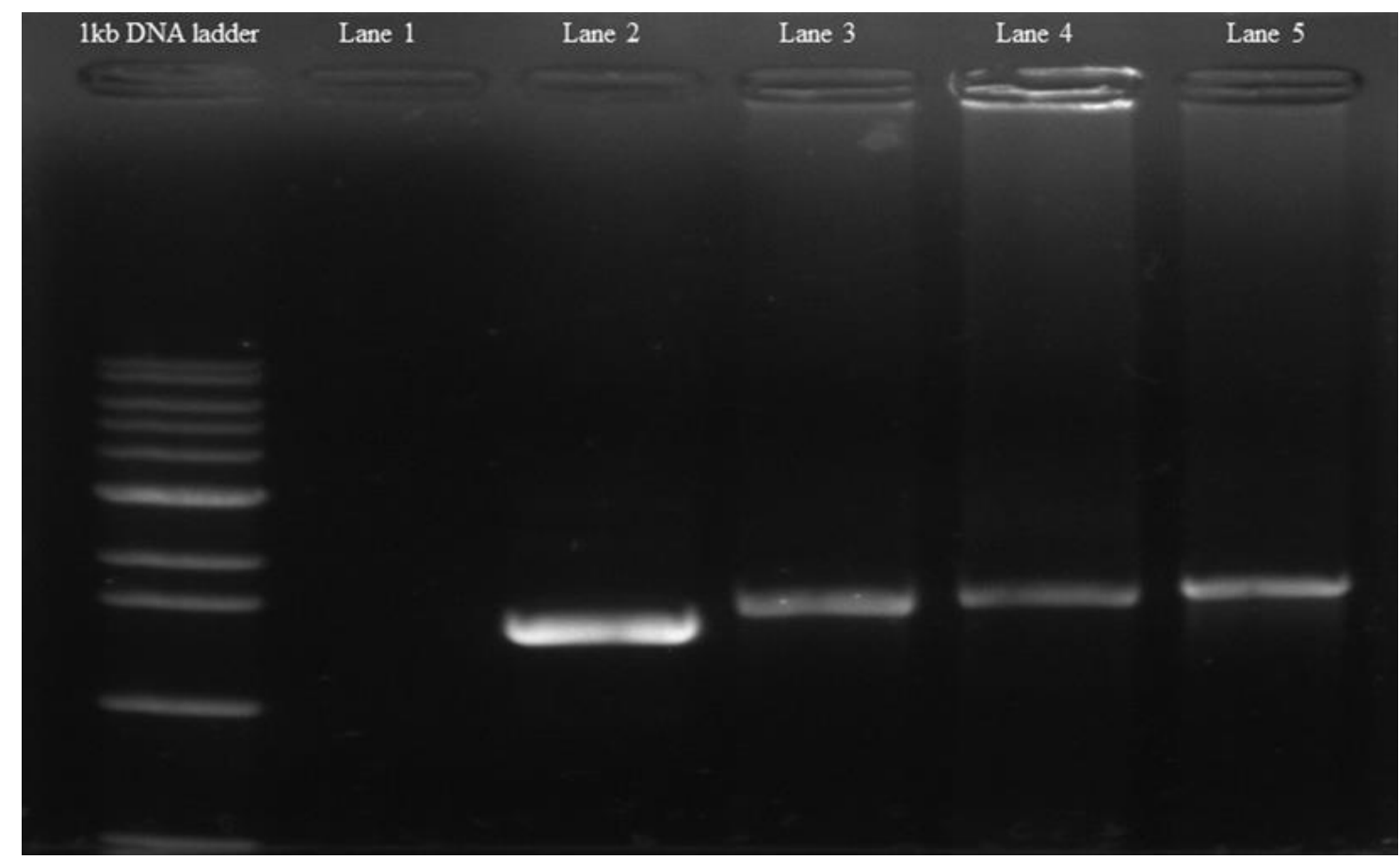

Figure 2 Agarose gel (1.2\%) showing PCR amplification of four putative glycosyltransferase genes in G. soja. Lane 1: negative control, Lange 2: Glyma10g107900.1, Lane 3: Glyma10g108400, Lane 4: Glyma10g104700.1 and Lane 5: Glyma10g1094000.

Broader utility of the protocol was examined by isolation of DNA from fresh leaves and seeds of four different Glycine species. We isolated DNA from G. max, G. soja, G. tomentella and G. lantifolia. All four species yielded higher quality and quantity of DNA (Table 5). Higher quality of extracted DNA was confirmed by PCR amplification of 5 microsatellites located on different linkage groups of G. soja. Clear banding pattern was observed in microsatellite analysis (Figure 1). Extracted DNA was also found amenable for PCR amplification of four putative glycosyltransferase genes (Gene ID:
Glyma10g107900.1, Glyma10g108400, Glyma10g104700.1 and Glyma10g1094000) (Figure 2). Similar approach was adopted by SAHU et al., (2012).

\section{Conclusions}

We report a competent, trouble free and simple CTAB DNA extraction method that provides high-quality DNA from Glycine species. The successful optimized DNA extraction method resulting in high quality genomic DNA from fresh trifoliate leaves as well as seeds of four 
Glycine species (G. soja, G. max, G. tomentella and G. lantifolia) demonstrated that the method has broad applications regarding Glycine species as well has fresh tissues or hard seeds. Pre-storage of fresh leaf tissues in $80{ }^{\circ} \mathrm{C}$ switched to low cost in comparison to use of costly liquid nitrogen. Use of $\beta$-mercaptoethanol, activated charcoal and sodium acetate supported extraction of higher quality DNA with no discoloration of pallet and no impurities. This CTAB method enables extraction of high quality of DNA amenable to PCR amplification of microsatellites as well as glycosyltransferase genes. Therefore, this method is recommended for DNA extraction from plant species for downstream applications.

\section{Acknowledgements}

This research was supported by Basic Science Research Program through the National Research Foundation of Korea (NRF) funded by the Ministry of Education (NRF-2015R1D1A1A09060925).

\section{Disclosure statement}

Authors declare no potential conflict of interest.

\section{References}

Bhau BS, Gogoi G, Baruah D, et al. 2015. Development of an effective and efficient DNA isolation method for Cinnamomum species. Food Chemistry, 188: 264-270.

Bressan EA, Rossi ML, Gerald LT, et al. 2014. Extraction of highquality DNA from ethanol-preserved tropical plant tissues. BMC Research Notes, 7: 268.

Chang S, Thurber CS, Brown PJ, et al. 2014. Comparative mapping of the wild perennial Glycine latifolia and soybean (G. max) reveals extensive chromosome rearrangements in the genus Glycine. PLoS ONE, 9: e99427.

Demeke T, Adams RP. 1992. The effects of plant polysaccharides and buffer additives on PCR. Biotechniques, 12: 332-334.

Dolatabadi JEN, Kashanian S. 2010. A review on DNA interaction with synthetic phenolic food additives. Food Res. Int., 43: 1223-1230.

Doyle JJ, Doyle JI. 1987. A rapid DNA isolation procedure for small quantities of fresh leaf tissue. Phytochem. Bull., 19: 1115.

Drabkova L, Kirschner JAN, Vlcek C. 2002. Comparison of seven DNA extraction and amplification protocols in historical herbarium specimens of Juncaceae. Plant Mol. Biol. Reports, 20: $161-175$.
Fang G, Hammar S, Grumet R. 1992. A quick and inexpensive method for removing polysaccharides from plant genomic DNA. Biotechniques, 13: 52-54.

Guo J, Wang Y, Song C, et al. 2012. A single origin and moderate bottleneck during domestication of soybean (Glycine max): implications from microsatellites and nucleotide sequences. Ann. Bot., 106: 505-514.

Haberer G, Fischer TC, Torres-Ruiz RA. 1996. Mapping of the nucleolus organizer region on chromosome 4 in Arabidopsis thaliana. Mol. Genet. Genomics, 250: 123-128.

Khanuja SP, Shasany AK, Darokar MP, et al. 1999. Rapid isolation of DNA from dry and fresh samples of plants producing large amounts of secondary metabolites and essential oils. Plant Mol. Biol. Reports, 17: 74-74.

Kit YS, Chandran S. 2013. A simple, rapid and efficient method of isolating DNA from Chokanan mango (Mangifera indica L.). Afric. J. Biotech., 9: 5805-5808.

Malencic D, Cvejic J, Miladinovic J. 2012. Polyphenol content and antioxidant properties of colored soybean seeds from Central Europe. Journal of Medicinal Food, 15:89-95.

Maliyakal JE. 1992. An efficient method for isolation of RNA and DNA from plants containing polyphenolics. Nucleic Acids Res., 20: 2381.

Manoj K, Tushar B, Sushama C. 2007. Isolation and purification of genomic DNA from Black Plum (Eugenia jambolana Lam.) for analytical applications. Int. J. Biotech. \& Biochem., 3: 49-55.

Mesquita ACO, Figueiro AA, Couto KR, et al. 2015. Optimization of soybean DNA extraction under different storage and development periods. J. Biosci., 31: 1102-1106.

Moreira PA, Oliveira DA. 2011. Leaf age affects the quality of DNA extracted from Dimorphandra mollis (Fabaceae), a tropical tree species from the Cerrado region of Brazil. Genet. \& Mol. Res., 10: 353-358.

Pirttila AM, Hirsikorpi M, Kamarainen T, et al. 2001. DNA isolation methods for medicinal and aromatic plants. Plant Mol. Bio. Rep., 19: 273-273.

Porebski S, Bailey LG, Baum BR. 1997. Modification of a CTAB DNA extraction protocol for plants containing high polysaccharide and polyphenol components. Plant Mol. Bio. Rep., 15: 8-15.

Sahu SK, Thangaraj M, Kathiresan K. 2012. DNA extraction protocol for plants with high levels of secondary metabolites and polysaccharides without using liquid nitrogen and phenol. Mol. Bio., 1-6.

Sharma AD, Gill PK, Singh P. 2002. DNA isolation from dry and fresh samples of polysaccharide-rich plants. Plant Mol. Bio. Rep., 20: 415-415.

Suman PSK, Ajit KS, Darokar MP, Kumar S. 1999. Rapid isolation of DNA from dry and fresh samples of plants producing large amounts of secondary metabolites and essential oils. Plant Mol. Bio. Rep. 17: 1-7.

Watson, RR. 2014. Polyphenols in Plants: Isolation, Purification and Extract Preparation. London: Academic Press. 